\title{
ACETYLPECTOLINARIN FROM SOME SPECIES OF Salvia
}

L. P. Smirnova, V. I. Glyzin,

UDC 547.972

A. V. Patudin, and A. I. Ban'kovski

The flavonoids diosmetin, luteolin, 6-methoxyluteolin, luteolin 7-glucoside, 6-methoxyluteolin 7-methyl ether, 7-O-methylluteolin, hispidulin, cosmosiin, genkwanin, 6-methoxygenkwanin, and salvigenin have previously been isolated from plants of the genus Salvia [sage] [1-6].

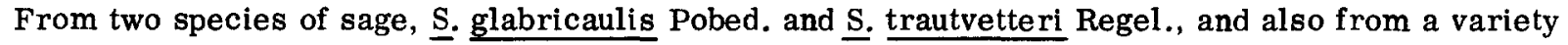
of the latter $-\underline{\mathrm{S}}$. trautvetteri var. karatavica - we have isolated a substance with the composition $\mathrm{C}_{31} \mathrm{H}_{36} \mathrm{O}_{16}$. $\mathrm{H}_{2} \mathrm{O}, \mathrm{mp} 242-244^{\circ} \mathrm{C}$ (from ethanol), $\lambda_{\max } 276,330 \mathrm{~nm}$ (in methanol).

Hydrolysis of this substance with $10 \%$ sulfuric acid gave an aglycone with $\mathrm{mp} 217-218^{\circ} \mathrm{C}$ corresponding according to its IR, UV, mass, and NMR spectra to pectolinarin, and sugars - glucose and rhamnose, identified by paper chromatography. The compound isolated gave no depression of the melting point with acetylpectolinarin [7], and the IR and NMR spectra of these substances coincided.

On the basis of the information given, we have identified the substance from the species of sage investigated as acetylpectolinarin.

\section{LITERATURE CITED}

1. É. V. Gella, V. I. Vavilov, and N. P. Beshko, Abstracts of the Second Symposium on Phenolic Compounds [in Russian], Alma-Ata (1970), p. 22.

2. N. Z. Sagdullaeva, R. L. Khazanovich, P. E. Krivenchuk, and A. I. Tikhonov, Abstracts of the Second Symposium on Phenolic Compounds [in Russian], Alma-Ata (1970), p. 45.

3. C. H. Brieskorn and W. Biechele, Quart. J. Crude Drug. Res., 11, No. 3, 1784 (1971).

4. C. H. Brieskorn and W. Biechele, Arch. Pharm. und Ber. Dtsch. Pharmaz. Ges., 304, No. 8, 557 (1971).

5. N. Lallement-Guilbert and L. Bezanger-Beauquesne, Plant Med. et Phytother, $\underline{4}$, No. 2, 92 (1970).

6. A. Ulubelen, S. Öztltrk, and S. Jsildatici, J. Pharmac. Sci., 57, No. 6, $1037(196 \overline{8})$.

7. L. P. Smirnova, G. G. Zapesochnaya, and A. I. Ban'kovskii, Abstracts of the Indo-Soviet Symposium on the Chemistry of Natural Compounds [in Russian], Tashkent (1973), p. 157.

All-Union Scientific-Research Institute of Medicinal Plants. Translated from Khimiya Prirodnykh Soedinenii, No. 2, p. 249, March-April, 1974. Original article submitted February 26, 1973.

(0) 1975 Plenum Publishizg Corporation, 227 West 17th Street, New York, N.Y. 10011. No part of this publication may be reproduced, stored in a retrieval system, or transmitted, in any form or by any means, electronic, mechanical, photocopying, microfilming, recording or otherwise, without written permission of the publisher. A copy of this article is available from the publisher for $\$ 15.00$. 